\title{
The Effect of Regional Generated Revenues and General Allocation Fund to Capital Expenditure and the Impact on Economic Growth in North Sumatera Province
}

\author{
Octreshia Ellendythia Marpaung \\ Department of Economics \\ State University of Medan \\ Medan, Indonesia \\ treshiamarpaung1@gmail.com \\ Indra Maipita ${ }^{2}$ \\ Department of Economics \\ State University of Medan \\ Medan, Indonesia \\ M. Fitri Rahmadana ${ }^{3}$ \\ Department of Economics \\ State University of Medan \\ Medan, Indonesia
}

\begin{abstract}
The economic growth in one region is influenced by local government policy and other factors that can affect the rate of economic growth such as local revenue, capital expenditure and balancing funds. Fixed assets such as infrastructure that can support economic activity is needed to stimulate economic growth. The purpose of this study is to analyze the effect of regional generated revenues and general allocation fund to capital expenditure and their impact on economic growth. The data which used in this study is secondary data of regional generated revenues and general allocation fund, capital expenditure and regional gross domestic product in thirty three districts/towns of North Sumatera Province for the period of 2010 to 2015. The analysis was used path analysis by using SPSS 23.0 for windows. The result of the research showed that simultaneously and partially regional generated revenues and general allocation fund have positive effect on capital expenditure and simultaneously regional generated revenues, general allocation fund and capital expenditure have positive effect on economic growth.
\end{abstract}

Keywords - economic growth; general allocation fund; regional generated revenues; capital expenditure

\section{INTRODUCTION}

Implementation of fiscal decentralization policy which stated in Law No. 32 of 2004 on Regional Government and Law no. 33 of 2004 on Fiscal Balance between Central and Regional Government, has provided opportunities for regions to increase local potential and improve financial performance to realize regional independence. The principle of regional autonomy used the principle of autonomy as far as possible in the sense that the regions are authorized to administer and regulate all government affairs outside the central government's affairs. Regions has authority to make the local policies to provide services, increase participation, initiatives, and community empowerment aimed at improving people's welfare [6].

Regional autonomy is based on the consideration that the regions are more aware of the conditions and what the community wants in their area. Regional autonomy is expected to increase services in various sectors, especially the public sector so as to attract investors to invest in the region. Based on these considerations, the implementation of regional autonomy is expected to be able to build the region optimally and spur economic growth and improving the welfare of the community.

The impact of the implementation of regional autonomy is the local government must explore the potential of regional income sources so as to increase regional generated revenues (PAD). PAD is the main source of revenue for a region. PAD obtained by a region comes from local taxes, regional levies, the result of separated regional wealth management, and other legitimate PAD. Increased PAD is expected to encourage better accountability, improve regional financing, and also to minimize the source of funding derived from the balance funds that directly increase the independence of the region. 
Implementation of regional autonomy also creates differences in the regional financial potential that can lead to the development gap between regions. To reduce the gap and support regional autonomy, the Government made Law Number 33 Year 2004 regarding Financial Balance between Central Government and Local Government. One of the balancing funds is the General Allocation Fund (DAU). The General Allocation Fund is a fund derived from the central government derived from the APBN allocated for the purpose of equitable distribution of finance between regions to finance the needs of local government expenditures in the implementation of decentralization. Local governments can use these funds to provide better services to the public.

Increased economic growth is a top priority of local governments. Economic growth can be achieved through the implementation of regional autonomy because it gives the local government the flexibility to manage, develop, and explore the potential of each region. Regional economic growth is proxied by using Gross Regional Domestic Product (PDRB). PDRB is the total value of goods and services obtained from all economic activities undertaken in the region. The economic growth rate of a region is calculated by PDRB at constant prices.

To realize the economic growth required fixed assets such as infrastructure and infrastructure facilities that can support economic activities. Development and addition of fixed assets is obtained through the allocation of capital expenditure. If the economic growth of a region increases, the local government will increase its capital expenditure to improve and equip infrastructure and infrastructure facilities in order to achieve better economic growth.

Government expenditure is part of fiscal policy, which is government action to create the economy by determining the amount of government revenues and expenditures annually, as reflected in the State Budget (APBN) for national and Regional Revenue Budget (APBD) for the region or region [11]. In undertake regional autonomy, it is necessary to have the authority and ability to explore its own financial resources supported by the financial balance between central and local governments, and between provinces and districts [1]. Regional Generated Revenues (PAD), General Allocation Fund (DAU) and Special Allocation Fund (DAK) are part of local government financial resources.

President Joko Widodo (Jokowi) on February 16, 2016 while chairing a limited meeting at the Presidential Office attended by North Sumatra Governor Tengku Erry Nuradi stated that the acceleration of infrastructure development, both port infrastructure and toll roads and airports is the key to economic growth. Infrastructure readiness will have an impact on the speed of development of special economic zones in Sei Mangkei as well as several other industrial estates being prepared as engines of economic growth in Sumatra. The availability of transport infrastructure will have a major impact on the speed of development and growth of the related economic region [14].
Increased output over time becomes an important indicator for measuring the success of a country's development [12]. Various factors affecting economic growth, especially the role of government is interesting to be studied more deeply. One of them are research of Mawarni, Darwanis and Abdullah (2013) which shows that simultaneously the result of path coefficient testing found that simultaneously PAD, DAU and capital expenditure have a positive effect on economic growth in districts / cities in Aceh Province. Partially capital expenditure does not affect economic growth in districts / municipalities in Aceh Province [7].

TABLE. 1 RECAPITULATION OF LOCAL ORIGINAL REVENUE (PAD), GENERAL ALLOCATION FUND (DAU), CAPITAL EXPENDITURE (BM) AND ECONOMIC GROWTH (PDRB) IN NORTH SUMATERA PROVINCE.

\begin{tabular}{|c|c|c|c|c|}
\hline YEAR & PAD & DAU & BM & PDRB \\
\hline 2010 & $1,254.42$ & $10,919.68$ & $3,274.41$ & $269,703.89$ \\
\hline 2011 & $1,922.10$ & $12,793.15$ & $4,661.17$ & $373,898.84$ \\
\hline 2012 & $2,369.42$ & $15,305.30$ & $5,696.61$ & $414,613.03$ \\
\hline 2013 & $2,761.49$ & $17,487.77$ & $7,097.30$ & $465,727.55$ \\
\hline 2014 & $3,598.42$ & $19,150.49$ & $7,127.59$ & $517,680.95$ \\
\hline 2015 & $3,865.98$ & $19,527.74$ & $7,794.25$ & $568,641.94$ \\
\hline \multicolumn{4}{|c|}{ Source : Central Bureau of Statistics of North Sumatera Province }
\end{tabular}

In Table 1 we can see that from 2010-2015 PAD, DAU and BM in North Sumatera Province increased and balanced with an increase in economic growth. So, it is necessary to examine the effect of revenue and allocation of local government capital expenditure in North Sumatra Province. The purpose of this research is to know the effect of PAD and DAU on capital expenditure (BM) and its effect on economic growth in regency / city in North Sumatera Province.

\section{LITERATURE REVIEW}

In Law No. 22/1997 article 79 on Regional Government, it is stated that the regional own-source revenue (PAD) is income derived from regional taxes, the results of regional retributions, the results of regional-owned enterprises, and the result of separated regional wealth management, other legitimate local revenue [5]. Government Regulation No.55 / 2005 on Balancing Fund, states that the General Allocation Fund (DAU) is a fund derived from APBN revenues allocated for the purpose of equitable inter-regional financial capacity to fund regional needs in the context of decentralization implementation [2]. The proportion of DAU for provinces and districts / municipalities shall be determined in accordance with the balance of authorities between provinces and districts / municipalities whose amount is set at least $26 \%$ of net domestic revenues set out in the APBN.

In the Perdirjen Perbendaharaan no. PER-33 / PB / 2008 concerning guidelines on the use of income ACCOUNTS, personnel expenditures, goods expenditures and capital expenditures in accordance with BAS, A spending is categorized as capital expenditure if : 
1.Such expenditures result in the acquisition of fixed assets or other assets that increase the life span, benefits and capacity.

2.The expenditure exceeds the minimum limit of the capitalization of fixed assets or other assets that the government has set.

3.Acquisitions of the property, plant and equipment are intended not for sale.

According Sukirno (2012), economic growth is a process of output increase per capita in a long term continuous [11]. Economic growth is one of the indicators used to evaluate the development or progress of economic development in a certain region in certain period, the economic growth rate is calculated from the change of Gross Regional Domestic Product (PDRB) at constant price from year to year.

The results of Valadkhani (1998) conducted in Iran, found that government capital expenditure has a positive and significant effect on GDP [13]. Kuncoro (2004) found that the development of facilities and infrastructure by the local government had a positive effect on economic growth [4].

Rumanti's research (2009) concluded that PAD has a positive and significant impact on economic growth [8]. The results of Sihite (2009) which concluded that DAU has a positive and significant impact on economic growth [9]. But the study contradicts the results of Isa's (2010) study concluding that DAU has no significant positive effect on economic growth [3].

\section{A. Hypotheses}

Referring to the foundation of the theory and previous research, it can be derived hypothesis as follows:

H1 : PAD and DAU simultaneously have a significant positive effect on capital expenditure.

$\mathrm{H} 2$ : PAD has a significant positive impact on capital expenditure.

H3 : DAU has a significant positive effect on capital expenditure.

H4 : PAD, DAU and Capital Expenditure simultaneously have a significant positive effect on Economic Growth.

H5 : PAD has a significant positive impact on Economic Growth.

H6: DAU has a significant positive effect on Economic Growth.

H7 : Capital Expenditure has a significant positive effect on Economic Growth.

\section{B. Research design}

Based on the research hypothesis, the research design can be described and made the regression equation as follows:
PICTURE.1 RESEARCH DESIGN

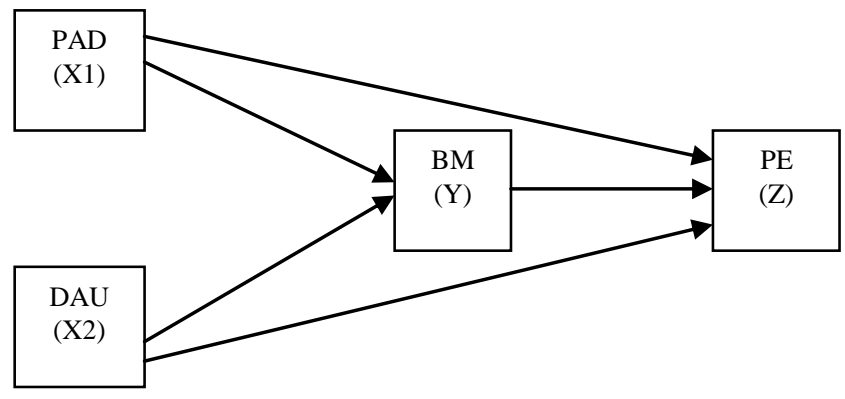

III. RESEARCH METHODS

Researchers used descriptive statistics and multiple linear regression to conduct path analysis of research variables. The type of data used in this study is secondary data, in the form of quantitative data which includes financial data of APBD realization of PAD data, DAU, capital expenditure and economic growth in thirty three districts/towns of North Sumatera Province for the period of 2010 to 2015. The data were obtained from the Central Bureau of Statistics and www.djkd.depkeu.go.id.

Methods of data analysis in this study using path analysis (path analysis). The hypothesis was tested by multiple linear regression method with extension of path analysis. Path analysis can be seen from standardized coefficient beta test and coefficient determination test. To test the hypothesis there are two research models, namely: To test hypotheses 1, 2 and 3 using the following equation:

$$
\mathrm{Y}=\mathrm{PYX} 1 \mathrm{X} 1+\mathrm{PYX} 2 \mathrm{X} 2+\rho \mathrm{Y} \varepsilon 1
$$

To test hypotheses 4, 5, 6 and 7 use the following equation:

$$
Z=P Z X 1 X 1+P Z X 2 X 2+P Z Y Y+\rho Z \varepsilon 2
$$

Information :

$$
\begin{array}{ll}
\mathrm{Z} & =\text { Economic growth } \\
\mathrm{Y} & =\text { Capital Expenditure } \\
\mathrm{X} 1 & =\mathrm{PAD} \\
\mathrm{X} 2 & =\mathrm{DAU} \\
\mathrm{P} & =\text { Regression coefficient } \\
\varepsilon 1 & =\text { Other variables that affect } \mathrm{Y} \\
\varepsilon 2 & =\text { Other variables affecting } \mathrm{Z}
\end{array}
$$

\section{RESULTS AND DISCUSSION}

Hypothesis testing on this research was conducted by using path analysis (analysis path), after all the classical assumptions in the test and found that the model can be used. 
A. Simultaneous Testing (F Test)

TABLE.2 F TEST FOR EQUATION 1

\begin{tabular}{|c|l|r|r|r|}
\hline Model & $\mathrm{R}$ & $\begin{array}{c}\mathrm{R} \\
\text { Square }\end{array}$ & $\begin{array}{c}\text { Adjusted } \\
\text { R Square }\end{array}$ & $\begin{array}{c}\text { Std. Error of } \\
\text { the Estimate }\end{array}$ \\
\hline 1 & $.870^{\mathrm{a}}$ & .758 & .755 & 64.89753 \\
\hline
\end{tabular}

a. Predictors: (Constant), DAU, PAD

b. Dependent Variable: BM

The results of data processing in table 2 obtained the value of $\mathrm{F}$ arithmetic amounted to 304,622 and significant value of $0.000<\mathrm{a}(0.05)$ which means simultaneously PAD and DAU significantly influence the Capital Expenditure. Thus, hipothesis 1 is accepted.

TABLE.3 F TEST FOR EQUATION 2

\begin{tabular}{|l|r|r|r|r|l|}
\hline \multicolumn{1}{|c|}{ Model } & \multicolumn{1}{c|}{ Sum of Squares } & \multicolumn{1}{c|}{ df } & \multicolumn{1}{c|}{ Mean Square } & \multicolumn{1}{c|}{ F } & \multicolumn{1}{c|}{ Sig. } \\
\hline Regression & 100786594005.643 & 3 & 33595531335.214 & 1175.857 & $.000^{\mathrm{b}}$ \\
Residual & 5542791865.621 & 194 & 28571092.091 & & \\
Total & 106329385871.264 & 197 & & & \\
& & & & \\
\hline
\end{tabular}

a. Dependent Variable: PDRB

b. Predictors: (Constant), BM, DAU, PAD

The results of data processing in table 3 obtained the value of $F$ arithmetic amounted to 1175,857 and significant value of $0.000<\mathrm{a}(0.05)$ which means simultaneously PAD, DAU and Capital Expenditures significantly influence on Economic Growth. Thus, hypothesis 4 is accepted.

\section{B. Partial Testing ( $t$ test)}

Table 4 shows that the standardized coeficient beta value for the PAD variable is 0.549 with the sig value. $0.000<\mathrm{a}$ (0.05), so it can be concluded that PAD has a positive effect on capital expenditure

TABLE 4. T TEST FOR EQUATION 1

\begin{tabular}{|c|c|c|c|c|c|}
\hline \multirow[b]{2}{*}{ Model } & \multicolumn{2}{|c|}{$\begin{array}{c}\text { Unstandardized } \\
\text { Coefficients }\end{array}$} & \multirow{2}{*}{$\begin{array}{c}\text { Standardized } \\
\text { Coefficients } \\
\text { Beta }\end{array}$} & \multirow[b]{2}{*}{$\mathrm{t}$} & \multirow[b]{2}{*}{ Sig. } \\
\hline & B & $\begin{array}{l}\text { Std. } \\
\text { Error }\end{array}$ & & & \\
\hline (Constant) & 55.034 & 11.264 & & 4.886 & .000 \\
\hline PAD & .354 & .030 & .549 & 11.664 & .000 \\
\hline DAU & .208 & .024 & .404 & 8.590 & .000 \\
\hline
\end{tabular}

Table 4 shows that the local government of regencies / cities in North Sumatera Province has been able to optimize the PAD owned to finance its regional capital expenditure. Thus, hypothesis 2 is accepted.

Standardized coeficient beta value of the DAU variable is 0.404 with the sig value. 0.000 so that can be concluded DAU have positive effect to capital expenditure. This means that the greater the transfer of funds given to the region then capital spending in the region will increase. Thus, hypothesis 3 is accepted
TABLE 5. COEFFICIENT OF DETERMINATION FOR EQUATION 1

\begin{tabular}{|c|c|c|c|c|c|}
\hline Model & $\begin{array}{c}\text { Sum of } \\
\text { Squares }\end{array}$ & df & Mean Square & $\mathrm{F}$ & Sig. \\
\hline Regression & 2565948.269 & 2 & 1282974.134 & 304.622 & $.000^{\mathrm{b}}$ \\
\hline Residual & 821279.339 & 195 & 4211.689 & & \\
\hline Total & 3387227.608 & 197 & & & \\
\hline
\end{tabular}

Table 5 shows Adjusted R Square of 0.755. This means that capital expenditure variable can be explained by variable of PAD and DAU equal to $75,5 \%$ while the rest $24,5 \%$ explained by other factors not explained in this research. Meanwhile, for the value of el can be calculated by e1 $=\sqrt{ }$ $((1-0.758))=0.492$.

TABLE 6. T TEST FOR EQUATION 2

\begin{tabular}{|c|c|c|c|c|c|}
\hline \multirow[b]{2}{*}{ Model } & \multicolumn{2}{|c|}{$\begin{array}{c}\text { Unstandardized } \\
\text { Coefficients }\end{array}$} & \multirow{2}{*}{$\begin{array}{c}\begin{array}{c}\text { Standar } \\
\text { dized } \\
\text { Coeffici } \\
\text { ents }\end{array} \\
\text { Beta }\end{array}$} & \multirow[b]{2}{*}{$\mathrm{t}$} & \multirow[b]{2}{*}{ Sig. } \\
\hline & B & $\begin{array}{l}\text { Std. } \\
\text { Error }\end{array}$ & & & \\
\hline (Constant) & -5588.417 & 982.864 & & -5.686 & .000 \\
\hline PAD & 86.525 & 3.260 & .756 & 26.539 & .000 \\
\hline DAU & 20.455 & 2.343 & .224 & 8.732 & .000 \\
\hline BM & 10.993 & 5.898 & .062 & 1.864 & .064 \\
\hline
\end{tabular}

a. Dependent Variable: PDRB

Table 6 shows that the standardized coeficient beta value for the PAD variable is 0.756 with the sig value. $0.000<\mathrm{a}$ (0.05), so it can be concluded that PAD has significant effect to economic growth. This is due to the increase in PAD and increase economic growth. Local governments are able to optimize the role of resources to increase economic growth. PAD obtained is used to improve the welfare of the community, for example for the public interest such as building roads, markets, hospitals and other infrastructure facilities that can improve people's welfare. Thus, hypothesis 5 is accepted.

Standardized coeficient beta value for the DAU variable is 0.224 with the sig value. $0.000<\mathrm{a}(0.05)$. This is because DAU received by the region is used for activities aimed at equitable distribution of economic growth among regions, so the role of DAU affects economic growth. DAU received by the regions is allocated for development expenditure as a means and infrastructure to increase economic growth. Thus, hypothesis 6 is accepted.

Standardized coeficient beta value for the Capital Expenditure variable is 0.062 with the sig value. 0.064> a (0.05). This shows that capital expenditure has no significant effect on economic growth. The results of this test support the results of research Mawarni, Darwanis and Abdullah (2013) that capital spending has no significant effect on economic growth. Thus, hypothesis 7 is rejected. 
TABLE 7. COEFFICIENT OF DETERMINATION FOR EQUATION 2

\begin{tabular}{|c|c|r|r|r|}
\hline Model & R & $\begin{array}{c}\text { R } \\
\text { Square }\end{array}$ & $\begin{array}{c}\text { Adjusted } \\
\text { R Square }\end{array}$ & $\begin{array}{c}\text { Std. Error of } \\
\text { the Estimate }\end{array}$ \\
\hline 1 & $.974^{\mathrm{a}}$ & .948 & .947 & 5345.19336 \\
\hline
\end{tabular}

a. Predictors: (Constant), BM, DAU, PAD

b. Dependent Variable: PDRB

Table 7 shows Adjusted R Square of 0.947. It means that the economic growth variable can be explained by the variable of PAD, DAU and capital expenditure of $94.7 \%$ while the remaining $5.3 \%$ is explained by other factors not explained in this research. Meanwhile, for the value of e 2 can be calculated by e $2=\sqrt{ }((1-0.948))=0.228$.

\section{Direct and Indirect Influence}

PICTURE 2. STRUCTURE OUTPUT

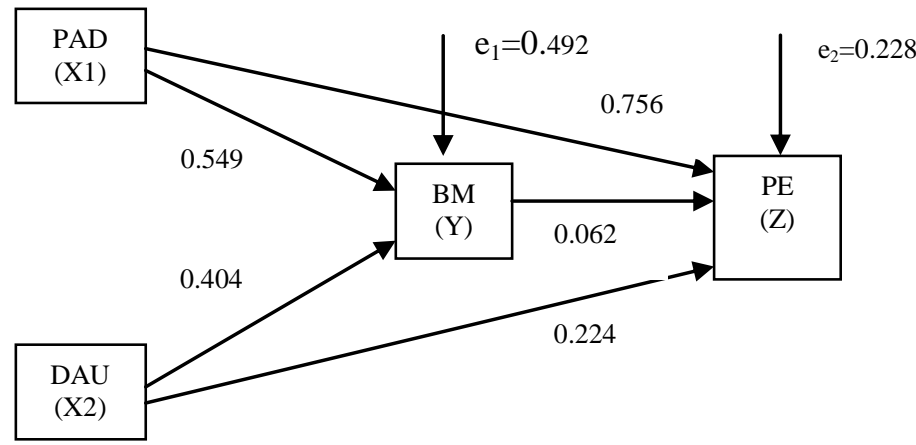

Based on the picture above is known that the value of direct influence PAD through Capital Expenditure on Economic Growth is amounted to 0.549 and the indirect influence is 0.034. The total effect of PAD on Economic Growth is 0.583 . It can be concluded that the direct effect of PAD on Economic Growth is bigger than the indirect effect of PAD through Capital Expenditure on Economic Growth.

The value of direct influence of DAU through Capital Expenditure on Economic Growth is 0.404 and indirect influence is 0.025. The total effect of DAU on Economic Growth is 0.429 . It can be concluded that the indirect effect of DAU through Capital Expenditure on Economic Growth is bigger than the direct impact of DAU on Economic Growth. The results indicate that indirect DAU through Capital Expenditure has a significant influence on economic growth

\section{CONCLUSIONS AND SUGGESTION}

\section{A. Conclusion}

The conclusions of this research are :

- The results show that simultaneously and partially PAD and DAU have positive effect on capital expenditure at regencies / cities in North Sumatera Province.
- The results show that simultaneously PAD, DAU and capital expenditure have positive effect on economic growth in regency / city in North Sumatera Province. While partially indicated that capital expenditure did not have an effect on to economic growth at district / city in North Sumatera Province.

- The results of the path coefficient test show that indirect DAU through Capital Expenditure has a significant influence on economic growth. While the direct influence of PAD on Economic Growth is bigger than the indirect effect of PAD through Capital Expenditure on Economic Growth.

\section{B. Suggestion}

The Suggestion of this study are :

1. To the district/city government of North Sumatra province :

- To be more active to increase economic growth by intensifying local revenue sources (PAD), because the increase in PAD directly affects the economic growth that will ultimately improve the welfare of the community.

- To prioritize the allocation of DAU and capital expenditure in areas directly related to the public interest, such as infrastructure or facilities that can promote economic growth.

- In order to the Provincial Government of North Sumatra to make regulations or regulations that can be related o capital expenditure budgeting that comes from oil and gas and special autonomy.

- For districts / municipalities to make a policy or scale of physical development priorities that are budgeted for regional capital expenditure so as to be in sync with the policy on the use of oil and gas funds and special autonomy in all districts / cities of Aceh Province.

2. To researchers, it is advisable to take more samples with longer time spans and add other variables, such as special allocation funds and profit-sharing funds.

\section{REFERENCES}

[1] Bratakusuma, Sholikin, (2001), Regional Development Planning. Jakarta: PT. Gramedia Pustaka Utama, 2003.

[2] Government Regulation Number.55 Year 2005 on Balancing Fund

[3] Isa, Filzah Mar'i., 2010, " Influence of General Allocation Fund (DAU), Special Allocation Fund (DAK) and Capital Expenditure to Economic Growth Level of Regency and City in North Sumatera Province ", Medan: FE USU

[4] Kuncoro, M., 2004. Autonomy and Regional Development: Reform, Economy, Strategy and Opportunity. Jakarta: Erlangga.

[5] Law of the Republic of Indonesia Number 22 Year 1997 on Regional Government

[6] Maryati,Ulfi and Endarwati (2010), "The Effect of Pendapatan Asli Daerah (PAD), General Allocation Fund (DAU) and Special Allocation Fund (OAK) on Economic Growth: Case Study of West Sumatera", 
Journal of Accounting \& Management, Vol.5, No.2, Desember 2010, pp 68-84.

[7] Mawarni, Darwanis and Syukriy Abdullah (2013), The Effect Of Income Of Original Regions And General Allocation Funds To Capital Shopping And The Impact Of Regional Economic Growth (Study On Regency And City In Aceh)", Journal of Graduate Accounting Syiah Kuala University, Vol.2, No.2, Mei 2013, pp 80-90.

[8] Rumanti, Indah Ari., 2009, "The Effect of Local Original Income (PAD) and General Aid Fund (DAU) on Economic Growth with Allocation of Capital Expenditure as Intervening Variable at Regency / City Se Java and Bali Province", Yogyakarta: faculty of Economics UMY.

[9] Sihite, Friska., 2009, " Effect of Original Regional Income, General Allocation Fund, Special Allocation Fund and Capital Expenditure on Regional Economic Growth in Regency / City of North Sumatera Province ", Medan: FE USU.

[10] Sugiyono.(2013). Business Research Methods. Bandung: Alfabeta

[11] Sukirno, Sadono. (2012). Micro Economic Theory Introduction. Jakarta: King GrafindoPersada

[12] Todaro, Michael P. and Smith Stephen C. (2015). Economic Development .Jakarta: Erland

[13] Valadkhani, A., 1998. Effect of Government Capital Expenditure on GDP in the Iranian Economy Using Superexogeneity Testing, Applied Economics Letters. No. 5. Hal: 361-364.

[14] www.lintasmedan.com 